\title{
In Vitro Influence of Prophylaxis Cleaning on Enamel Remineralization with Casein Phosphopeptide-Amorphous Calcium Phosphate
}

\author{
Mona Zeitouny ${ }^{1}$, Hasan Fayyad-Kazan², Herve Tassery ${ }^{3,4}$, Hussein Fayyad-Kazan ${ }^{5}$ \\ ${ }^{1}$ Department of Restorative and Esthetic, Faculty of dentistry, Lebanese University, Hadath, Lebanon. \\ ${ }^{2}$ Faculty of Dentistry, Lebanese University, Hadath, Lebanon. \\ ${ }^{3}$ Laboratoire Bioingénierie et Nanoisciences, Montpellier University, Montpellier, France. \\ ${ }^{4}$ Aix Marseille University, Marseille, France. \\ ${ }^{5}$ Laboratory of Cancer Biology and Molecular Immunology, Faculty of Sciences I, Lebanese University, Hadath, Lebanon.
}

\author{
Corresponding Author: \\ Mona Zeitouny \\ Department of Restorative and Esthetic Faculty of Dentistry \\ Lebanese University \\ Lebanon \\ Phone: 0096171873508 \\ E-mail: monazeitouny@live.com
}

\begin{abstract}
Objectives: This randomized controlled in vitro 4-arm trial study aimed to study the remineralization potential of Recaldent ${ }^{\mathrm{TM}}$ and assess the effects of prophylaxis cleaning and MI Varnish ${ }^{\circledR}$ on enhancing this remineralization potential.

Material and Methods: Sixty human teeth were randomly assigned into equal samples (A/B). Sample A was prophylactically cleaned, randomly divided into equal samples (1/2). Sample A1 received treatment with MI Varnish ${ }^{\circledR}$ and Recaldent ${ }^{\mathrm{TM}}$ for 30 days. Sample A2 was treated similarly but without MI Varnish ${ }^{\circledR}$. Sample B did not receive prophylaxis cleaning and was divided into equal samples (1/2). Sample B1 was treated as A1 and sample B2 as A2. The teeth were examined for mineral composition at baseline, after the interventions (T1), and after prophylaxis cleaning (T2). Study outcomes were mineral content $(\%$ weight of carbon $[\mathrm{C}]$, phosphorus $[\mathrm{P}]$, calcium $[\mathrm{Ca}]$, oxygen $[\mathrm{O}]$, chlorine $[\mathrm{Cl}]$, sodium $[\mathrm{Na}]$ and silicon $[\mathrm{Si}])$ and calcium-phosphorus ratio $(\mathrm{Ca} / \mathrm{P})$.

Results: All groups had similar mineral composition at baseline. At T1, sample B2 exhibited least P, Ca and Ca/P content. Samples A1 and B1 showed higher content of P and Ca, compared to B2 (A1 only exhibited higher Ca/P). Sample A2 exhibited lowest $\mathrm{Cl}$ and $\mathrm{Na}$ content. At T2, sample A1 exhibited lowest $\mathrm{C}, \mathrm{P}, \mathrm{O}$ and Si content (highest Ca/P). Sample A2 showed least $\mathrm{Ca} / \mathrm{P}$, and highest $\mathrm{Na}$ content.

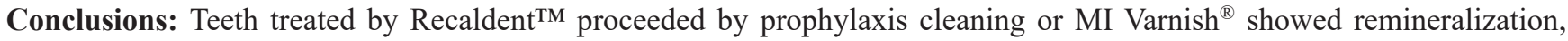
especially when receiving both interventions. This superior effect persisted even after a second cleaning. Further trials are necessary to provide conclusive evidence in humans.
\end{abstract}

Keywords: calcium phosphates; dental caries; dental enamel; tooth demineralization; tooth remineralization.

Accepted for publication: 11 March 2020

To cite this article:

Zeitouny M, Fayyad-Kazan H, Tassery H, Fayyad-Kazan H.

In Vitro Influence of Prophylaxis Cleaning on Enamel Remineralization with Casein Phosphopeptide-Amorphous Calcium Phosphate

J Oral Maxillofac Res 2020;11(1):e4

URL: http://www.ejomr.org/JOMR/archives/2020/1/e4/v11n1e4.pdf

doi: $\underline{10.5037 / \text { jomr.2020.11104 }}$ 


\section{INTRODUCTION}

Dental caries is the most common dental disease and highly prevalent chronic diseases worldwide [1]. Dental caries affects people of all age groups, and individuals remain susceptible to this disease throughout their lifetime [1].

Caries formation is a dynamic process, resulting from an imbalance between demineralization and remineralization of enamel and dentin [2], whereby the minerals dissolve, leading to the destruction of the enamel and degradation of the mechanical properties of the dentin [3]. Dental caries is usually not self-limiting, and without proper care, caries can progress until the tooth is destroyed, leading to pain, discomfort and more severe oral diseases [4]. In addition, dental caries considerably affects the quality of life, and along with its treatment, pose a substantial economic burden on societies, thus considered as a significant global public health problem $[\underline{5}, \underline{6}]$, requiring cost-effective measures. In the last decade, a paradigm shift emerged in international dentistry clinical practice, and the current focus is to move away from operative intervention towards preventive caries management, i.e. biological approach [7], and the prevention by controlling the demineralization/ remineralization activity [,, 9$]$. Specifically, dental research has shown the importance of calcium and phosphate ions in the remineralization process [10], and casein phosphopeptide-amorphous calcium phosphate (CPP-ACP) has gained increasing importance in this regards $[\underline{11}, \underline{12}]$.

CPP is a milk-derived protein able to bind calcium and phosphate ions, and stabilize them as ACP [13] CPP-ACP adheres intraorally to plaque pellicle, hydroxyapatite as well as soft tissues, and was shown to buffer the free calcium and phosphate ion activities, maintain a state of super-saturation with respect to tooth enamel, prevent enamel demineralization, and promote remineralization [14]. A series of studies and systematic reviews $[\underline{15}, \underline{16}]$ have reported an anti-caries effect of CPP-ACP. CCP-ACP with $0.2 \%$ sodium fluoride (Recaldent ${ }^{\mathrm{TM}}$ GC Corporation; Tokyo, Japan) is delivered in many forms including tooth mousse, toothpastes, mouth rinses, chewing gums, sports drinks, as well as in dental varnishes $[\underline{11}, \underline{17}]$.

The remineralization effect of Tooth Mousse Recaldent $^{\mathrm{TM}}$ (GC America Inc; Illinois, USA) can be modulated. For instance, CPP-ACP agents have higher remineralizing potential when applied with fluoridated agents $[\underline{18}, 19]$.

To date, there is no evidence about the synergistic remineralization potential of Recaldent ${ }^{\mathrm{TM}}$ and other interventions of interest, namely, dental prophylaxis cleaning. The latter is a procedure performed to thoroughly clean the teeth. This study aims to study the remineralization potential of CPP-ACP (Recaldent ${ }^{\mathrm{TM}}$; Melbourne, Australia) by quantifying the changes in the tooth's mineral content using scanning electron microscopy-energy-dispersive $\mathrm{X}$-ray (SEM/EDX) and assess the effects of prophylaxis cleaning and application of MI Varnish ${ }^{\circledR}$ (GC Corporation; Tokyo, Japan) on enhancing the remineralization potential of this agent.

\section{MATERIAL AND METHODS}

The study design and protocol were reviewed and approved by the Institutional Review Board (approval number: CUMEB/D166/42019).

\section{Materials}

- Recaldent ${ }^{\mathrm{TM}}$. Commercial GC MI Paste Plus ${ }^{\circledR}$ (GC America Inc; Illinois, USA) was used. This formulation contains $20 \%$ glycerol; $10 \%$ CPPACP; 5\% D-glucitol; 2\% sodium carboxyl methyl cellulose (CMC-Na); $2 \%$ propylene glycol; $2 \%$ titanium dioxide; $0.2 \%$ sodium fluoride, among other components [20].

- MI Varnish ${ }^{\circledR}$. Commercial GC MI Varnish ${ }^{\circledR}$ was used, containing between $25-50 \%$ ethanol, and 2.5 - 5\% sodium fluoride [21].

- Artificial saliva (Pickering Laboratories, Inc.; Mountain View, California, USA) was formulated according to published literature in medical and dental research, and has a similar composition to commercially available products used to treat dry mouth and other conditions. This ready-to-use solution contains sodium carboxymethyl cellulose to increase its viscosity and make it behave like the human saliva. This formulation has a $\mathrm{pH}$ of 6.8 and can be stored at room temperature [22].

\section{Samples}

A power analysis was conducted using G*Power Software, version 3.1.9.2 (Heinrich-Heine-Universität, Düsseldorf, Germany). Considering the repeated measures design of the trial, and accounting for an effect size of 0.2 (small effect size), a $5 \%$ level of significance and an $80 \%$ power, the required sample size was around 60 teeth.

The sample consisted of sixty human teeth (molar: $\mathrm{n}=35$; pre-molar: $\mathrm{n}=25$ ) extracted for orthodontic and periodontal reasons with signed patient agreement. The teeth were visually assessed for 
the presence of caries using the International Caries Detection and Assessment System II (ICDAS II) [23]]. ICDAS II is a universal 7-point ordinal scale that detects early lesions, as well as changes in the longitudinal follow-up. Teeth having ICDAS score from 0 to score 3 were included, as follows:

- Score 0 - no evidence of visible caries;

- Score 1 - first visual change in enamel;

- Score 2 - distinct visual change in enamel;

- Score 3 - localized enamel breakdown with no visible dentin or underlying shadow.
The teeth were rinsed with water and stored in a $0.1 \%$ thymol solution at a $\mathrm{pH}$ of 7 , for 1 hour to avoid any contamination with bacteria. Afterward, the teeth were rinsed with water and examined for mineral composition. The occlusal surface of the teeth was targeted.

\section{Procedures}

The teeth were randomly assigned into 2 equal sample: sample A and B. (Figure 1).

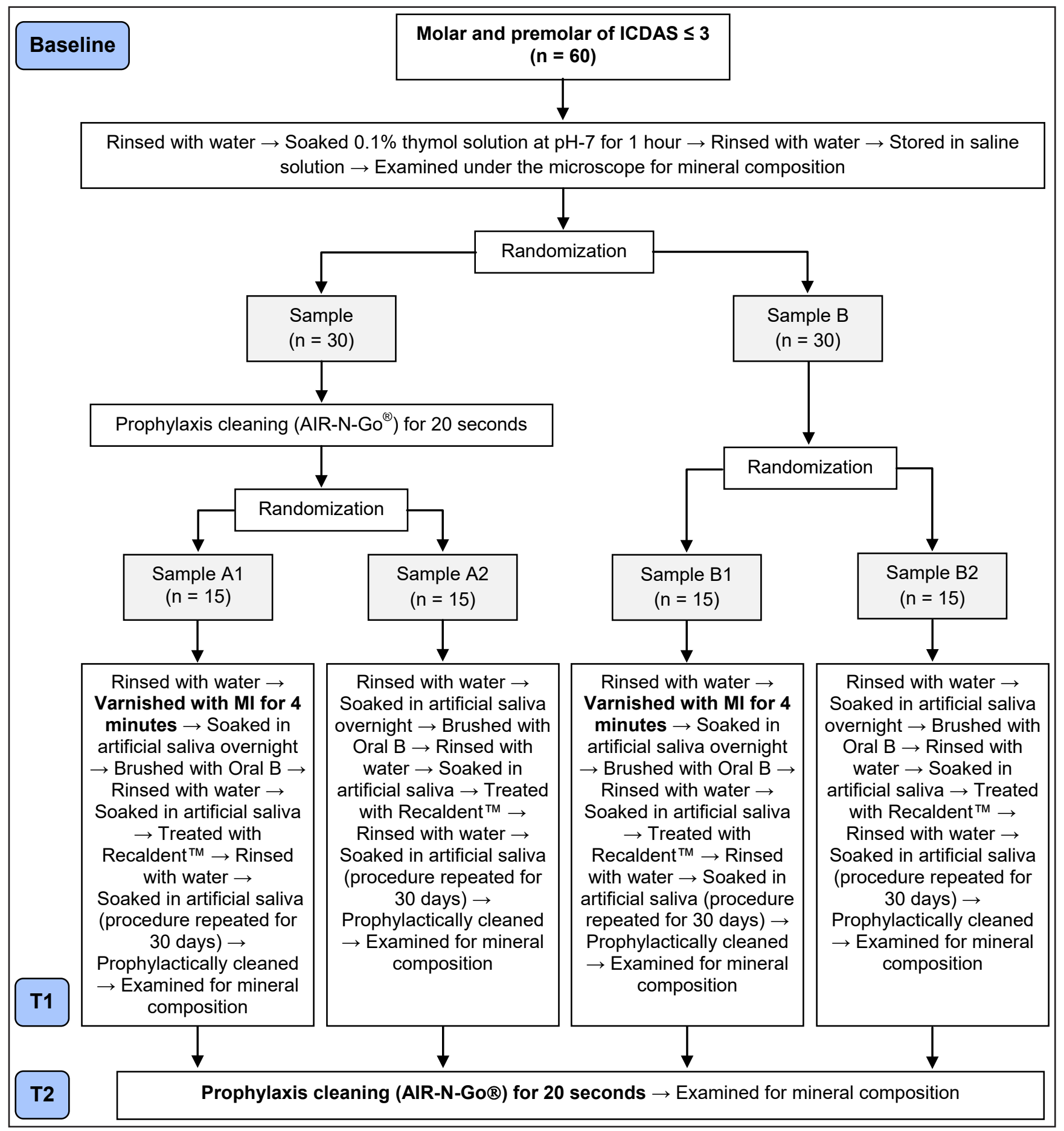

Figure 1. Flow chart of the laboratory process during this study. 
Sample A teeth $(\mathrm{n}=30$; molar: $\mathrm{n}=15$; pre-molar: $\mathrm{n}=15$ ) received prophylaxis cleaning for 20 seconds, using AIR-N-GO ${ }^{\circledR}$ (Acteon; Bordeaux, France) combining water, air and pearl powder (natural calcium-carbonate-based, diameter: $55 \mu \mathrm{m}$ ), at $1 \mathrm{~mm}$ distance from the surface.

The cleaned 30 teeth were then randomly assigned into 2 equal samples: sample 1 and 2 .

Sample A1 teeth $(\mathrm{n}=15$; molar: $\mathrm{n}=8$; pre-molar: $\mathrm{n}=7$ ) were rinsed with water, had MI Varnish ${ }^{\circledR}$ applied according to manufacturer instructions for 4 minutes using a micro-brush on the surface to ensure homogenization. The teeth were then soaked with artificial saliva overnight. In the morning, the teeth were brushed with Oral- $\mathrm{B}^{\circledR}$ brush (Oral B Laboratory; Kildare, Ireland) and rinsed with water, and soaked again in artificial saliva until night. Next, sample A1 teeth were rinsed with water and treated with Tooth Mousse Recaldent ${ }^{\mathrm{TM}}$ (CPP-ACP) for 4 minutes. The teeth were then gently brushed with a micro-brush on the surface, and then soaked again in artificial saliva. Sample A1 teeth underwent the same procedures for 30 days. After that, the teeth were examined for mineral composition (T1). This was followed by a prophylaxis cleaning and examination for mineral composition for all groups (T2).

Sample A2 teeth $(\mathrm{n}=15$; molar: $\mathrm{n}=7$; pre-molar: $\mathrm{n}=8$ ) underwent the same series of interventions as sample A1 teeth, but without being treated by MI Varnish $^{\circledR}$.

Sample B teeth $(\mathrm{n}=30$; molar: $\mathrm{n}=19$; pre-molar: $\mathrm{n}=11)$ served as controls, thus were not initially cleaned prophylactically.

These teeth were equally assigned to 2 samples: sample 1 and 2.

Sample B1 teeth $(\mathrm{n}=15$; molar: $\mathrm{n}=11$; pre-molar: $\mathrm{n}=4$ ) received the same intervention as sample $\mathrm{A} 1$ teeth; and sample B2 teeth $(\mathrm{n}=15$; molar: $\mathrm{n}=8$; pre-molar: $\mathrm{n}=7$ ) received the same treatment as sample A2 teeth. All of sample B teeth were also examined for mineral composition.

The mineral composition of products used for all procedures was also analysed.

\section{Analysis of chemical composition}

The specimens were evaluated for mineral content (\% weight) and calcium-phosphorus ratio $(\mathrm{Ca} / \mathrm{P})$ at baseline, T1 and T2 using SEM/EDX.

Study outcomes were the content of carbon (C), phosphorus $(\mathrm{P}), \mathrm{Ca}$, oxygen $(\mathrm{O})$, chlorine $(\mathrm{Cl})$, sodium $(\mathrm{Na})$ and silicon $(\mathrm{Si})$ in addition to $\mathrm{Ca} / \mathrm{P}$. The latter was calculated by dividing the $\%$ weight of $\mathrm{Ca}$ by that of $P$.
Scanning electron microscopy with SEM/EDX is the best known and most widely-used surface analytical technique. SEM/EDX detects elements as light as Boron, and its detection limits range between 100\% and $0.1 \%$ weight. Besides elemental composition, this system allows digital image acquisition for highquality secondary and backscattered electron images. Accordingly, high resolution images of surface topography (from 2 to $50 \mathrm{~nm}$ ), with excellent depth of field (range 0.5 to $3 \mu \mathrm{m}$ ), are produced using a highly-focused scanning (primary) electron beam. The analysed area ranges from $10 \times 10 \mathrm{~mm}$ to $1 \times 1$ $\mu \mathrm{m}$, and the size of the accommodated sample is up to $200 \mathrm{~mm}$ diameter and $80 \mathrm{~mm}$ depth. For the analysis, the primary electrons enter a surface with an energy of 0.5 to $30 \mathrm{kV}$ and engender numerous low energy secondary electrons. The intensity of the latter is mostly governed by the sample's surface topography. Consequently, an image of the sample surface is constructed by measuring secondary electron intensity as a function of the position of the scanning primary electron beam. The primary electron beam can be focused to a very small spot $(<10 \mathrm{~nm})$ allowing a high spatial resolution. Using a primary electron beam with energy of $<1 \mathrm{kV}$, high sensitivity to topographic features on the outermost surface $(<5 \mathrm{~nm})$ is achieved. Along with low energy secondary electrons, primary electron bombardment backscattered electrons generate X-rays. The intensity of backscattered electrons can be correlated to the atomic number of the element within the sampling volume, allowing qualitative elemental information to be obtained; the analysis of characteristic X-rays emitted from the sample provides additional quantitative elemental information. SEM, complemented by X-ray analysis, is a relatively inexpensive, rapid, and nondestructive approach to surface analysis; and is often used to survey surface analytical problems before proceeding to more surface-sensitive and specialized techniques such as SIMS, RBS.

In this study the samples were carefully placed on a sample holder, using sterile tweezers in order to prevent any external contamination, and fixed by a double-faced conductive tape on one side, while the other side was freely facing the electron beam of the SEM. Sputter Coater 108 Auto (Cressington Scientific Instruments, Inc., Watford, UK) was used to metalize the surface of the samples with gold. A high vacuum SEM, model AIS2100 (Seron Technologies Inc.; Gyeonggi-do, Korea) with an acceleration voltage of $20 \mathrm{kV}$ and a working distance of $25 \mathrm{~mm}$, coupled to an EDAX Apollo X detector (AMETEK; Berwyn, Pennsylvania, USA) at a take-off angle of 23 degrees were used for all EDX measurements. 


\section{Statistical analysis}

The normality of the data was checked using Kolmogorov-Smirnov test. In each group, the values for these outcome variables were compared using Wilcoxon Signed Ranks test. Change in mineral content between the 4 groups of comparison was assessed using Kruskal Wallis Test, and that between two groups using Mann Whitney $\mathrm{U}$ test. $\mathrm{P}<0.05$ was considered significant with a Bonferroni correction where multiple comparisons were conducted. The Statistical Package for Social Sciences (IBM SPSS), version 21 was used for statistical analysis. Parametric data were expressed as mean and standard deviation $(\mathrm{M}[\mathrm{SD}])$.

\section{RESULTS}

At baseline, the 4 compared groups exhibited similar mineral composition of $\mathrm{C}, \mathrm{P}, \mathrm{Ca}$, and $\mathrm{O}$, as well as $\mathrm{Ca} / \mathrm{P}(\mathrm{P}>0.05$ for all tested variables). Table 1 showed the average value of the different components in the 60 teeth.
At $\mathrm{T} 1$, the teeth that did not undergo initial prophylaxis cleaning and were not varnished with MI (B2) exhibited the least content in $\mathrm{P}, \mathrm{Ca}$ and $\mathrm{Ca} / \mathrm{P}$. Initially applying MI Varnish ${ }^{\circledR}$ with or without prophylaxis cleaning (A1 and B1, respectively) resulted in enhanced content of $\mathrm{P}$ and $\mathrm{Ca}$, compared with the fourth group (B2); yet, A1 group only exhibited a higher $\mathrm{Ca} / \mathrm{P}$. On the other hand, the teeth undergoing initial prophylaxis cleaning without being varnished by MI (A2) exhibited the lowest content of $\mathrm{Cl}$ and $\mathrm{Na}$ as shown in Table 2.

At T1, prophylaxis cleaning without MI Varnish ${ }^{\circledR}$ enhanced the mineralization effect of Recaldent ${ }^{\mathrm{TM}}$ on all studied minerals, whereby the sample A2 teeth exhibited at $\mathrm{T} 1$ a significantly higher concentration

Table 1. Baseline mineral content of the 60 extracted teeth, $\%$ weight

\begin{tabular}{l|c|c}
\hline Mineral content & Mean & Standard deviation \\
\hline Carbon (C) & 29.17 & 9.65 \\
\hline Phosphorous (P) & 12.62 & 3.55 \\
\hline Calcium (Ca) & 18.47 & 5.77 \\
\hline Oxygen (O) & 38.94 & 2.21 \\
\hline
\end{tabular}

Table 2. Effect of different treatments on the mineralization effect of Recaldent ${ }^{\mathrm{TM}}$ at $\mathrm{T} 1(\mathrm{n}=60)$

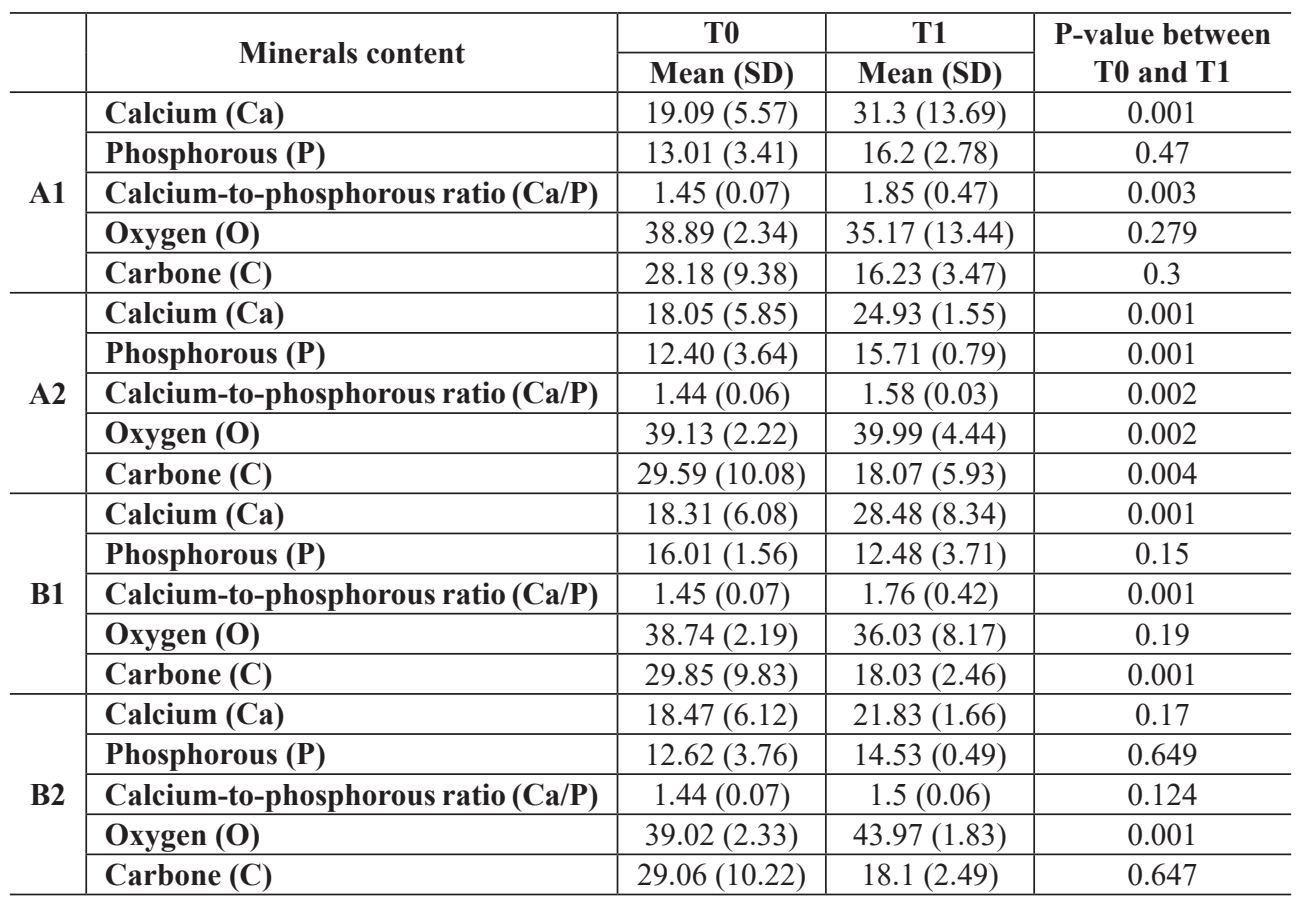

Intergroup difference P-value: calcium 0.001; phosphorous 0.002; calcium-to-phosphorous ratio 0.01; oxygen 0.061 ; carbone 0.0406 . $\mathrm{A} 1=$ sample underwent prophylaxis cleaning, followed by application of MI Varnished, and treatment with Recaldent ${ }^{\mathrm{TM}}$.

$\mathrm{A} 2$ = sample underwent prophylaxis cleaning, followed by treatment with Recaldent ${ }^{\mathrm{TM}}$.

$\mathrm{B} 1=$ sample underwent application of MI Varnished, followed by treatment with Recaldent ${ }^{\mathrm{TM}}$.

$\mathrm{B} 2$ = sample underwent only treatment with Recaldent ${ }^{\mathrm{TM}}$.

Kruskal-Wallis test was used for change in mineral content between the 4 groups (A1, A2, B1, B2) of comparison.

Mann Whitney U test was used for between 2 groups (A1 and A2; A1 and B1; A1 and B2; A2 and B1; A2 and B2; B1 and B2).

Bonferroni correction was applied where multiple comparisons were conducted (A1 with A2 and A1 with B2 and A2 with B2).

$\mathrm{SD}=$ standard deviation . 
in $\mathrm{P}, \mathrm{Ca}, \mathrm{Ca} / \mathrm{P}$ and $\mathrm{O}$. Applying MI Varnish ${ }^{\circledR}$ only (B1) resulted in increasing $\mathrm{C}, \mathrm{Ca}$ and $\mathrm{Ca} / \mathrm{P}$. Applying both interventions (prophylaxis cleaning and $\mathrm{MI}$ Varnish $^{\circledR}$ [A1]) resulted in increasing Ca content and $\mathrm{Ca} / \mathrm{P}$ only. Nevertheless, increasing $\mathrm{Ca} / \mathrm{P}$ was most accentuated in this group of teeth. The absence of these interventions (B2) did not affect the mineral composition of the teeth, except for an increase in $\mathrm{O}$ content, as shown in Table 2 and Figure 2.

Following the second cleaning procedure, i.e. at T2, teeth receiving prophylaxis cleaning with MI Varnish ${ }^{\circledR}$ (A1) exhibited the lowest $\mathrm{C}, \mathrm{P}, \mathrm{O}$ and $\mathrm{Si}$ content, yet the highest $\mathrm{Ca} / \mathrm{P}$. In contrast, teeth undergoing prophylaxis cleaning without MI Varnish ${ }^{\circledR}$ (A2) showed the least $\mathrm{Ca} / \mathrm{P}$, and the highest $\mathrm{Na}$ content, as detailed in Table 3.

\section{DISCUSSION}

This in vitro study evaluated the remineralization potential of CPP-ACP (Recaldent ${ }^{\mathrm{TM}}$ ) using SEM/ EDX and assessed the impact of prophylaxis cleaning and application of MI Varnish ${ }^{\circledR}$ on enhancing the remineralization potential of this agent. The study assessed as well the impact of a second prophylaxis cleaning on the remineralization potential of Recaldent $^{\mathrm{TM}}$. The latter procedure was done in order to explore whether the remineralization effectiveness will be reduced.

Among the 60 teeth that were studied, the ones receiving treatment by Tooth Mousse Recaldent ${ }^{\mathrm{TM}}$ proceeded by either prophylaxis cleaning or MI Varnish ${ }^{\circledR}$ showed remineralization; the most remineralization effect was seen in those receiving both interventions, and this superior effect persisted even after a second cleaning.

The results of our study are consistent with the proposed remineralization mechanism of CPP-ACP after a short duration use, e.g. 1 month [24] and are in accordance with the available literature on the effects of Tooth Mousse Recaldent ${ }^{\mathrm{TM}}$ in inhibiting demineralization and enhancing remineralization or possibly both [16].

In the oral environment, CPP-ACP binds to biofilms, plaque, bacteria, hydroxyapatite, and soft tissue, buffers the free $\mathrm{Ca}$ and phosphate ion activities and increases the degree of saturation by $\mathrm{Ca}$ and $\mathrm{P}$ with respect to hydroxyapatite. Thus CPP-ACP localizes bioavailable ions and subsequently ACP on the tooth surface [15].

Only, a very limited number of studies had evaluated factors modifying the remineralization potential of CPP-ACP quantitatively, especially the $\mathrm{Ca}$ and $\mathrm{P}$ content, and $\mathrm{Ca} / \mathrm{P}$ of enamel $[\underline{18}, \underline{19}]$. In our study, applying Tooth Mousse Recaldent ${ }^{\mathrm{TM}}$ in conjunction with prophylaxis cleaning (A2) or MI Varnish ${ }^{\circledR}$ alone (B1), or simultaneously with both interventions (A1) resulted in a continuously increased mineral content values $(\mathrm{Ca} / \mathrm{P})$, even after a second prophylaxis cleaning. Yet, this was most accentuated in the latter group (A1), i.e. the group receiving prophylaxis cleaning and MI Varnish ${ }^{\circledR}$. This provides evidence on the superiority of combining these interventions over

Table 3. Effect of additional cleaning on the mineral content of teeth at $\mathrm{T} 2(\mathrm{n}=45)$

\begin{tabular}{l|c|c|c|c}
\hline \multirow{2}{*}{\multicolumn{1}{c|}{ Minerals content }} & A1 & A2 & B2 & \multirow{2}{*}{ P-value } \\
\cline { 2 - 5 } & Mean (SD) & Mean (SD) & Mean (SD) & \\
\hline Calcium (Ca) & $38.05(13.22)$ & $24.31(0.88)$ & $25.7(2.24)$ & 0.024 \\
\hline Phosphorous (P) & $14.86(0.15)$ & $15.88(1.24)^{\mathrm{a}}$ & $15.63(0.78)^{\mathrm{a}}$ & 0.006 \\
\hline Calcium-to-phosphorous ratio (Ca/P) & $2.55(0.86)^{\mathrm{a}, \mathrm{b}}$ & $1.53(0.06)^{\mathrm{a}}$ & $1.64(0.07)^{\mathrm{b}}$ & $<0.001$ \\
\hline Oxygen (O) & $33.07(8.93)^{\mathrm{a}, \mathrm{b}}$ & $40.85(3.15)^{\mathrm{a}}$ & $36.67(2.78)^{\mathrm{b}}$ & 0.003 \\
\hline Carbone (C) & $11.89(3.98)$ & $15.9(4.65)^{\mathrm{a}}$ & $20.2(1.55)^{\mathrm{a}}$ & $<0.001$ \\
\hline Chlorine (CI) & $0.46(0.04)$ & $0.46(0.22)$ & $0.42(0.26)$ & 0.407 \\
\hline Sodium $(\mathbf{N a})$ & $0.88(0.09)^{\mathrm{a}}$ & $1.05(0.22)^{\mathrm{a}}$ & $0.87(0.23)$ & 0.033 \\
\hline Silicon $(\mathbf{S i})$ & $0.32(0.09)^{\mathrm{a}, \mathrm{b}}$ & $1.12(0.48)^{\mathrm{a}, \mathrm{c}}$ & $0.49(0.15)^{\mathrm{b}, \mathrm{c}}$ & $<0.001$ \\
\hline
\end{tabular}

${ }^{a}$ Corrected P-value at $<0.016$ indicate significant differences.

${ }^{\mathrm{b}}$ Corrected P-value at $<0.016$ indicate significant differences.

${ }^{\mathrm{c}}$ Corrected P-value at $<0.016$ indicate significant differences.

$\mathrm{A} 1$ = sample underwent prophylaxis cleaning, followed by application of MI Varnished, and treatment with Recaldent ${ }^{\mathrm{TM}}$.

$\mathrm{A} 2$ = sample underwent prophylaxis cleaning, followed by treatment with Recaldent ${ }^{\mathrm{TM}}$.

$\mathrm{B} 2=$ sample underwent only treatment with Recaldent ${ }^{\mathrm{TM}}$.

Kruskal-Wallis test was used for change in mineral content between the 3 groups (A1, A2, B2) of comparison.

Mann Whitney U test was used for between 2 groups (A1 and A2; A1 and B2; A2 and B2).

Bonferroni correction was applied where multiple comparisons were conducted (A1 with A2 and A1 with B2 and A2 with B2).

$\mathrm{SD}=$ standard deviation 


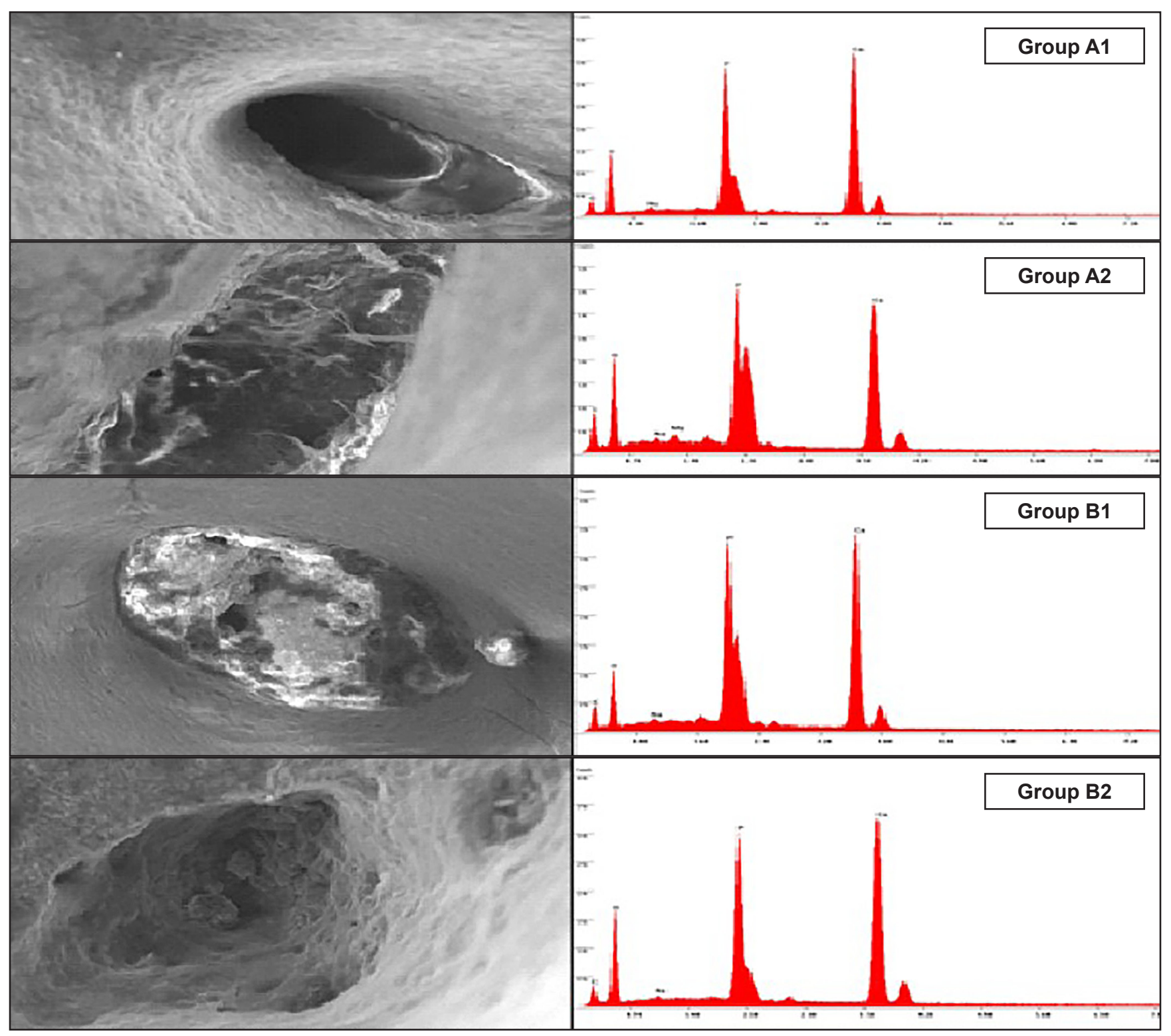

Figure 2. Scanning electron microscopy photomicrographs of enamel surface with its energy dispersive X-ray in the four groups.

the use of either intervention alone in enhancing the remineralizing effect of CPP-ACP. This superior effect is potentially attributed to the use of MI Varnish ${ }^{\circledR}$ in addition to Tooth Mousse Recaldent ${ }^{\mathrm{TM}}$ which helps drive beneficial ions into the tooth, enhances enamel acid resistance, and boosts the salivary fluoride level $[\underline{25}, \underline{26}]$, but also to the prophylaxis cleaning consisting of a complete removal of plaque, salivary pellicle, materia alba and extrinsic stains found on the teeth, thus allowing a direct contact and better adhesion between CPP-ACP and the teeth [27].

It is worthy to note that the $\mathrm{Si}$ found in the studied teeth at T2 relates to the application of MI Varnish ${ }^{\circledR}$ and Tooth Mousse Recaldent ${ }^{\mathrm{TM}}$ products which contain this mineral.

Although the present study could not completely simulate the complex oral environment, its results still demonstrated the remineralization effectiveness of the
$\mathrm{CPP}-\mathrm{ACP}$ in an in vitro environment, and the role of prophylaxis cleaning and MI Varnish ${ }^{\circledR}$ in enhancing this remineralization effect. Further shortcomings of the present study are the small sample size, which potentially limits our ability to detect statistical significance. Also, although the evaluation of remineralizing effect was done by using SEM/ EDX which is considered the gold standard for the evaluation of mineral loss or gain in experimentally induced initial caries lesions [28], we acknowledge its inherent limitations in elemental analysis [29], e.g. its inability to distinguish between ionic and nonionic species, and its influence by inter-element interference (peak overlap), causing serious problems in the elemental analysis, especially for elements with low atomic number $(\mathrm{C}, \mathrm{Cl}, \mathrm{P}, \mathrm{Na}$ and $\mathrm{Si})$. Moreover, we are limited by our ability to generalize our results, as the exact composition of enamel varies between teeth, 
and between different individuals [30], especially that our sample was not chosen at random nor representative of the target population. Finally, our greatest limitation lies in the mineral content of products used, i.e. MI Varnish ${ }^{\circledR}$, AIR-N-Go ${ }^{\circledR}$, Tooth Mousse Recaldent ${ }^{\mathrm{TM}}$, which could have affected our results and increased the mineral content of assessed teeth especially after the second prophylactic cleaning.

\section{CONCLUSIONS}

Within the limitations of the study, it can be concluded that prophylaxis cleaning and MI Varnish ${ }^{\circledR}$ enhance the remineralization effect of casein phosphopeptide-amorphous calcium phosphate in teeth showing no evidence of visible caries and those characterized by the first clinically non-cavitated visual changes in enamel. Further clinical trials are necessary to provide conclusive evidence on the findings of this study in humans.

\section{ACKNOWLEDGMENTS AND DISCLOSURE STATEMENTS}

We thank Dr. Roland Habchi, from the research platform for nanoscience and nanotechnology at the Lebanese University for his help in conducting the analysis of chemical composition.

\section{REFERENCES}

1. Selwitz RH, Ismail AI, Pitts NB. Dental caries. The Lancet. 2007 Jan 6;369(9555):51-9. [doi: 10.1016/S0140-6736(07)60031-2]

2. Featherstone JD. The science and practice of caries prevention. J Am Dent Assoc. 2000 Jul;131(7):887-99. [Medline: 10916327] [doi: 10.14219/jada.archive.2000.0307]

3. Bertassoni LE, Habelitz S, Marshall SJ, Marshall GW. Mechanical recovery of dentin following remineralization in vitro--an indentation study. J Biomech. 2011 Jan 4;44(1):176-81. [Medline: 20926080] [PMC free article: 3003773] [doi: 10.1016/j.jbiomech.2010.09.005]

4. Zero DT, Brennan MT, Daniels TE, Papas A, Stewart C, Pinto A, Al-Hashimi I, Navazesh M, Rhodus N, Sciubba J, Singh M, Wu AJ, Frantsve-Hawley J, Tracy S, Fox PC, Ford TL, Cohen S, Vivino FB, Hammitt KM; Sjögren's Syndrome Foundation Clinical Practice Guidelines Committee. Clinical practice guidelines for oral management of Sjögren disease: Dental caries prevention. J Am Dent Assoc. 2016 Apr;147(4):295-305. [Medline: 26762707] [doi: 10.1016/j.adaj.2015.11.008]

5. Petersen PE, Bourgeois D, Ogawa H, Estupinan-Day S, Ndiaye C. The global burden of oral diseases and risks to oral health. Bull World Health Organ. 2005 Sep;83(9):661-9. [Medline: 16211157] [PMC free article: 2626328]

6. Schwendicke F. Contemporary concepts in carious tissue removal: A review. J Esthet Restor Dent. 2017 Nov 12;29(6): 403-408. [Medline: 28925550] [doi: 10.1111/jerd.12338]

7. Pitts NB. Are we ready to move from operative to non-operative/preventive treatment of dental caries in clinical practice? Caries Res. 2004 May-Jun;38(3):294-304. [Medline: 15153703] [doi: 10.1159/000077769]

8. Tyas MJ, Anusavice KJ, Frencken JE, Mount GJ. Minimal intervention dentistry--a review. FDI Commission Project 1-97. Int Dent J. 2000 Feb;50(1):1-12. [Medline: 10945174] [doi: 10.1111/j.1875-595X.2000.tb00540.x]

9. Hemagaran G, Neelakantan P. Remineralization of the tooth structure-the future of dentistry. Int J PharmTech Res. 2014 Apr-Jun;6(2):487-93. [URL: http://sphinxsai.com/2014/PTVOL6/PT=11(487-493)AJ14.pdf]

10. Longbottom C, Ekstrand K, Zero D, Kambara M. Novel preventive treatment options. Monogr Oral Sci. 2009;21: 156-163. [Medline: 19494683] [doi: 10.1159/000224220]

11. Farooq I, Moheet IA, Imran Z, Farooq U. A review of novel dental caries preventive material: Casein phosphopeptideamorphous calcium phosphate (CPP-ACP) complex. King Saud Uni Dent Sci. 2013 Jul 1;4(2):47-51. [doi: 10.1016/j.ksujds.2013.03.004]

12. Baroni C, Marchionni S, Bazzocchi MG, Cadenaro M, Nucci C, Manton DJ. A SEM and non-contact surface white light profilometry in vivo study of the effect of a crème containing CPP-ACP and fluoride on young etched enamel. Scanning. 2014 Mar-Apr;36(2):270-7. [Medline: 23843169] [doi: 10.1002/sca.21102]

13. Reynolds EC. Anticariogenic complexes of amorphous calcium phosphate stabilized by casein phosphopeptides: a review. Spec Care Dentist. 1998 Jan-Feb;18(1):8-16. [Medline: 9791302] [doi: 10.1111/j.1754-4505.1998.tb01353.x]

14. Cochrane NJ, Reynolds EC. Calcium phosphopeptides -- mechanisms of action and evidence for clinical efficacy. Adv Dent Res. 2012 Sep;24(2):41-7. [Medline: 22899678] [doi: 10.1177/0022034512454294]

15. Manoharan V, Kumar RK, Sivanraj AK, Arumugam SB. Comparative Evaluation of Remineralization Potential of Casein Phosphopeptide- Amorphous Calcium Fluoride Phosphate and Novamin on Artificially Demineralized Human Enamel: An In vitro Study. Contemp Clin Dent. 2018 Jun;9(Suppl 1):S58-S63. [Medline: 29962765] [PMC free article: 6006878] [doi: 10.4103/ccd.ccd_28_18]

16. González-Cabezas C, Fernández CE. Recent Advances in Remineralization Therapies for Caries Lesions. Adv Dent Res. 2018 Feb;29(1):55-59. [Medline: 29355426] [doi: 10.1177/0022034517740124] 
17. Andrian S, Stoleriu S, Tărăboanţă I, Gamen AC, Dîmbu E, Negraia D. Remineralization of incipient enamel lesions using non-fluoride agents. A review. Int J Med Dent. 2018 Jan-Mar;22(1):41-9. [URL: https://www.ijmd.ro/2018/vol-22-issue-1/]

18. Reynolds EC. Calcium phosphate-based remineralization systems: scientific evidence? Aust Dent J. 2008 Sep;53(3): 268-73. [Medline: 18782374] [doi: 10.1111/j.1834-7819.2008.00061.x]

19. Fahad AH, Al-Weheb AM. Effect of casein phosphopeptide-amorphous calcium phosphate on the microhardness and microscopic features of the sound enamel and initial caries-like lesion of permanent teeth, compared to fluoridated agents. J Bagh Coll Dent. 2012;24(4):114-20. [URL: https:/www.iasj.net/iasj?func=article\&aId=70173]

20. [Directive $n^{\circ}$ 91/155/CEE du 05/03/91 définissant et fixant, en application de l'article 10 de la directive 88/379/CEE du Conseil, les modalités du système d'information spécifique relatif aux préparations dangereuses]. 2006 Dec 30. [URL: https://www.tooth-mousse.fr/GC_MI Paste_Plus\%20securite.pdf]

21. Safety data sheet. According to 1907/2006/EC, Article 31. Version number 3.2015 Sep 2. [URL: http://sea.gcasiadental.com/Upload/product/pdf/1/MSDS-MI-Varnish.pdf]

22. Artificial saliva for medical and dental research. Pickering Test Solutions: Artificial Body Fluids for Product Testing Applications. Pickering Laboratories, Inc. 2019. [URL: https://www.pickeringtestsolutions.com]

23. Pitts NB, Stamm JW. International Consensus Workshop on Caries Clinical Trials (ICW-CCT)--final consensus statements: agreeing where the evidence leads. J Dent Res. 2004;83 Spec No C:C125-8. [Medline: 15286139] [doi: 10.1177/154405910408301s27]

24. Shaik ZA, Rambabu T, Sajjan G, Varma M, Satish K, Raju VB, Ganguru S, Ventrapati N. Quantitative Analysis of Remineralization of Artificial Carious Lesions with Commercially Available Newer Remineralizing Agents Using SEM-EDX- In Vitro Study. J Clin Diagn Res. 2017 Apr;11(4):ZC20-ZC23. [Medline: 28571254] [PMC free article: 5449910] [doi: 10.7860/JCDR/2017/22270.9642]

25. DiGangi P. The Goldilocks principle: Finding a caries treatment that fits right. 2017 Aug 22. [URL: https://www.dentistryiq.com/articles/2017/08/the-goldilocks-principle-finding-a-caries-treatment-that-fits-right. $\underline{\text { html] }}$

26. Majithia U, Venkataraghavan K, Choudhary P, Trivedi K, Shah S, Virda M. Comparative evaluation of application of different fluoride varnishes on artificial early enamel lesion: An in vitro study. Indian J Dent Res. 2016 Sep-Oct;27(5):521-527. [Medline: 27966511] [doi: 10.4103/0970-9290.195642]

27. Azarpazhooh A, Main PA. Efficacy of dental prophylaxis (rubber cup) for the prevention of caries and gingivitis: a systematic review of literature. Br Dent J. 2009 Oct 10;207(7):E14; discussion 328-9. [Medline: 19816459] [doi: $10.1038 /$ sj.bdj.2009.899]

28. Tranaeus S, Al-Khateeb S, Björkman S, Twetman S, Angmar-Månsson B. Application of quantitative lightinduced fluorescence to monitor incipient lesions in caries-active children. A comparative study of remineralisation by fluoride varnish and professional cleaning. Eur J Oral Sci. 2001 Apr;109(2):71-5. [Medline: 11347658] [doi: 10.1034/j.1600-0722.2001.00997.x]

29. Scimeca M, Bischetti S, Lamsira HK, Bonfiglio R, Bonanno E. Energy Dispersive X-ray (EDX) microanalysis: A powerful tool in biomedical research and diagnosis. Eur J Histochem. 2018 Mar 15;62(1):2841. [Medline: 29569878] [PMC free article: 5907194] [doi: 10.4081/ejh.2018.2841]

30. Finke M, Hughes JA, Parker DM, Jandt KD. Mechanical properties of in situ demineralised human enamel measured by AFM nanoindentation. Surf Sci. 2001 Oct 1;491(3):456-67. [doi: 10.1016/S0039-6028(01)01311-5]

\section{To cite this article:}

Zeitouny M, Fayyad-Kazan H, Tassery H, Fayyad-Kazan H.

In Vitro Influence of Prophylaxis Cleaning on Enamel Remineralization with Casein Phosphopeptide-Amorphous Calcium Phosphate

J Oral Maxillofac Res 2020;11(1):e4

URL: http://www.ejomr.org/JOMR/archives/2020/1/e4/v11n1e4.pdf

doi: $10.5037 /$ jomr.2020.11104

Copyright (C) Zeitouny M, Fayyad-Kazan H, Tassery H, Fayyad-Kazan H. Published in the JOURNAL OF ORAL \& MAXILLOFACIAL RESEARCH (http://www.ejomr.org), 31 March 2020.

This is an open-access article, first published in the JOURNAL OF ORAL \& MAXILLOFACIAL RESEARCH, distributed under the terms of the Creative Commons Attribution-Noncommercial-No Derivative Works 3.0 Unported License, which permits unrestricted non-commercial use, distribution, and reproduction in any medium, provided the original work and is properly cited. The copyright, license information and link to the original publication on (http://www.ejomr.org) must be included. 